\title{
INDUSTRIAL CARBON DIOXIDE EMISSIONS AND POTENTIAL GEOLOGICAL SINKS IN THE BALTIC STATES
}

\author{
S. SLIAUPA ${ }^{(\mathrm{a}, \mathrm{b})}$, A. SHOGENOVA ${ }^{(\mathrm{c})^{*}}, \mathrm{~K}$. SHOGENOV ${ }^{(\mathrm{c})}$, \\ R. SLIAUPIENE ${ }^{(\mathrm{a})}, \mathrm{A}$ ZABELE $^{(\mathrm{d})}, \mathrm{R}^{(\mathrm{c})}$ VAHER $^{(\mathrm{c})}$
}

a Institute of Geology and Geography, T. Sevčenkos 13, Lt-03223, Vilnius, Lithuania

b Vilnius University, Universiteti St. 3, LT-01513, Vilnius, Lithuania

c Institute of Geology, Tallinn University of Technology, Ehitajate tee 5, 19086 Tallinn, Estonia

d Faculty of Geographical and Earth Sciences, University of Latvia, Rainis Blvd. 19, LV-1586, Riga, Latvia

\begin{abstract}
Industrial $\mathrm{CO}_{2}$ emissions and geological storage opportunities in Estonia, Latvia and Lithuania are studied within the framework of EU GEOCAPACITY and CO2NET EAST projects supported by European Commission through Framework Programme 6. The structure of the energy sector and socio-economic conditions vary considerably between these three countries. A total of 24 large (emitting more than 0.1 million tonnes (Mt) of $\mathrm{CO}_{2}$ ) industrial sources of $\mathrm{CO}_{2}$ emissions, registered in 2005 in the European Trading Scheme, consists of $11.5 \mathrm{Mt}$ of $\mathrm{CO}_{2}$ from Estonia, 1.9 Mt from Latvia and 5.6 Mt from Lithuania. The highest amount of $\mathrm{CO}_{2}$ emission in Estonia is related to the oil shale used as the main fuel for power generation; the two largest Estonian power plants - Estonian and Baltic - produced respectively 7.7 and $2.25 \mathrm{Mt}$ of $\mathrm{CO}_{2}$ in 2005 and 9.4 and $2.7 \mathrm{Mt}$ of $\mathrm{CO}_{2}$ in 2007. $\mathrm{CO}_{2}$ emission from oil shale combustion is significantly higher in comparison with other fossil fuels as energy sources. This is why $\mathrm{CO}_{2}$ emission per capita in Estonia is about two times higher than the average value in Europe.

The three Baltic States are located within the Baltic sedimentary basin, the thickness of which varies from $100 \mathrm{~m}$ in Northeast Estonia up to $1900 \mathrm{~m}$ in Southwest Latvia and $2300 \mathrm{~m}$ in West Lithuania. The most prospective formation for geological storage of $\mathrm{CO}_{2}$ is the Cambrian reservoir. 15 large structures have been identified in Latvia with a total capacity exceeding $300 \mathrm{Mt}$ of $\mathrm{CO}_{2}$. The tightness of structures is evidenced by 40 years of successful operation of the Inčukalns Underground Gas Storage. Due to shallow setting, geological conditions in Estonia are unfavourable for $\mathrm{CO}_{2}$ storage. Therefore an option of transporting $\mathrm{CO}_{2}$ from Estonia via pipelines
\end{abstract}

\footnotetext{
* Corresponding author: e-mail alla@gi.ee
} 
to one of the Latvian storage structures could be considered. Alternatively, the technology of $\mathrm{CO}_{2}$ trapping by sorption of oil shale ash is under development in Estonia. In Lithuania, the capacity of $\mathrm{CO}_{2}$ storage in Cambrian and Devonian structures as well as in oil fields is negligible, but $\mathrm{CO}_{2}$ solubility and mineral trapping is a long-term option.

\section{Inroduction}

Most of the energy used to meet human needs is derived from combustion of fossil fuels (natural gas, oil, coal, oil shale, etc.), which release carbon dioxide into the atmosphere. Combustion of oil shale, the main energy resource of Estonia, produces significantly higher $\mathrm{CO}_{2}$ emissions per energy produced than other energy sources. Globally about $23.5 \mathrm{Gt}$ of $\mathrm{CO}_{2}$ was emitted from fossil fuel use in 2000 [1]. The atmospheric concentration of $\mathrm{CO}_{2}$, a greenhouse gas, is increasing, causing trapping of solar heat and subsequent global warming. As a result of human activities, the $\mathrm{CO}_{2}$ concentration in the atmosphere has risen from pre-industrial $280 \mathrm{ppmv}$ to $380 \mathrm{ppmv}$ and might reach $1100 \mathrm{ppmv}$ by 2100 [2]. Global warming studies predict that climate changes, resulting from increase in atmospheric concentration of $\mathrm{CO}_{2}$, will adversely affect life on the Earth [3].

Carbon management consists of a broad portfolio of strategies to reduce carbon emissions via carbon capture and storage, enhanced efficiency of power generation and use, application of low-carbon fuels and the employment of renewable energy sources [4]. Carbon dioxide is already being captured in oil and gas and chemical industries. Once $\mathrm{CO}_{2}$ has been captured, it would need to be stored securely for hundreds and thousands of years. $\mathrm{CO}_{2}$ has been used for enhanced oil recovery (EOR) purposes since the 1950s [5]. Research concerning sequestration of $\mathrm{CO}_{2}$ for environmental purposes began only $10-15$ years ago. $\mathrm{CO}_{2}$ sequestration in geological media can be safely undertaken within national boundaries in most countries, thus avoiding international political issues. Geological sinks for $\mathrm{CO}_{2}$ include depleted oil and gas reservoirs, enhanced oil recovery, unminable coal seams, and deep saline porous formations. Together, these can hold hundreds to thousands of gigatonnes of carbon $(\mathrm{GtC})$, and the technology to inject $\mathrm{CO}_{2}$ into the ground is well established. $\mathrm{CO}_{2}$ is stored in geological formations by a number of different trapping mechanisms, with the particular mechanism depending on the formation type [4, 6-15].

According to the Kyoto protocol signed by the Baltic countries in 2002, the level of air-polluting greenhouse gases emissions should be reduced by $8 \%$ during the commitment period 2008-2012 compared to the 1990 level. Compared to 1990, the greenhouse gas (GHG) emissions decreased in Baltic countries for more than 50\% [16-18], Table 1a. However, the changing energy market (e.g. closure of the Ignalina NPP) and increasing industrial growth urge to evaluate different options of reducing $\mathrm{CO}_{2}$ emissions, including the assessment of the potential of geological sinks. Furthermore, the inventory of 
geological storage of $\mathrm{CO}_{2}$ in the Baltic countries became an integrated part of the European-scale projects, like EU GEOCAPACITY and CO2NET EAST.

Table 1a. Total greenhouse gas (GHG) emissions and $\mathrm{CO}_{2}$ emissions per capita

\begin{tabular}{|l|c|c|c|c|c|}
\hline \multirow{2}{*}{} & \multicolumn{3}{|c|}{ Total GHG emissions } & $\mathrm{CO}_{2}$ emissions per head \\
\cline { 2 - 6 } & \multicolumn{2}{|c|}{$\begin{array}{c}\text { In } \mathrm{CO}_{2} \text { equivalents, } \\
\text { million tonnes }\end{array}$} & $\begin{array}{c}\text { Reduction compared } \\
\text { to } 1990, \%\end{array}$ & $\begin{array}{c}\text { Tonnes } \\
\mathrm{CO}_{2} / \text { capita }\end{array}$ & $\begin{array}{c}\text { Place in } \\
\text { world rate }\end{array}$ \\
\hline \multicolumn{1}{|c|}{ Year } & 1990 & \multicolumn{2}{|c|}{2005} & \multicolumn{2}{|c|}{2004} \\
Estonia & 42.6 & 20.9 & 50.9 & 14.1 & 16 \\
Latvia & 26.4 & 10.9 & 58.9 & 3.87 & 90 \\
Lithuania & 48 & 22.6 & 53 & 3.07 & 100 \\
\hline
\end{tabular}

The geological setting of the Baltic States is rather different from that of the other European countries that comprise a number of small sedimentary basins, while Lithuania, Latvia and Estonia are situated within one common Baltic sedimentary basin [19]. Therefore, a joint study is required for the assessment of geological sinks. The source types and emissions differ considerably in the Baltic countries, depending on the socio-economic conditions. The main energy and $\mathrm{CO}_{2}$ in Estonia comes from oil shale combustion, while $\mathrm{CO}_{2}$ emissions in Lithuania and Latvia are significantly lower due to the utilisation of other main energy sources (nuclear and hydro-energy). Geological conditions are also different, as these countries represent different parts of the Baltic basin. The composition and properties of reservoir rocks of the Baltic Cambrian basin were studied some years ago in the framework of the Baltic-German project GEOBALTICA [20-24]. The estimation of carbon capture and storage capacity was recently started in Lithuania [25]. The capacity of Latvian structures for the purpose of underground gas storage was assessed in 2007 by Latvian Environment, Geology and Meteorology Agency (LEGMA) [26]. In 2006 all three Baltic countries started inventory of their $\mathrm{CO}_{2}$ industrial sources and geological capacity in the framework of EU GEOCAPACITY project supported by EU Framework Programme 6 [27].

\section{Distribution and types of stationary $\mathrm{CO}_{2}$ sources}

In 1990 (base year of the Kyoto Protocol) the Baltic countries produced $48 \mathrm{Mt}$ of GHG emissions in $\mathrm{CO}_{2}$ equivalents in Lithuania, $42.6 \mathrm{Mt}$ in Estonia and 26.4 Mt in Latvia. The emissions have reduced considerably since this basic year, due to large-scale socio-economic rearrangement of the Baltic countries. In 2005 these emissions were reduced for 53\% in Lithuania, 51\% in Estonia and $59 \%$ in Latvia compared to the basic year (Table 1a). However, GHG emissions have increased systematically since 1999-2000 owing to 
economical growth [16-18]. A significant increase in emissions is forecasted in Lithuania due to the planned closure of the Ignalina NPP in 2009.

The largest GHG emissions in the Baltic countries are produced by the energy sector (Table $1 \mathrm{~b}$ ), while contribution from other sectors is much less significant [16-18]. $\mathrm{CO}_{2}$ sources exceeding 100000 tonnes/year are only considered economically feasible for geological sequestration. Twenty four large sources (Fig. 1) produced $11.5 \mathrm{Mt}$ of $\mathrm{CO}_{2}$ in Estonia, $5.6 \mathrm{Mt}$ in Lithuania and $1.9 \mathrm{Mt}$ in Latvia. The stationary sources included into the European Union Emission Trading Scheme (EU ETS) produced $12.7 \mathrm{Mt}$ of $\mathrm{CO}_{2}$ in Estonia (41 sources), 6.6 Mt in Lithuania (89 sources) and $2.98 \mathrm{Mt}$ in Latvia (89 sources). In Estonia, $\mathrm{CO}_{2}$ emission per capita amounting 14.1 tonnes is one of the highest in Europe and in the world, while reaching 3.87 and 3.07 tonnes in Lithuania and Latvia, respectively (Table 1a). For the sake of comparison it should be noted that in 2004 average $\mathrm{CO}_{2}$ emissions per capita was 7.7 tonnes in Europe.

Table $1 b$. Share of sectors (\%) in greenhouse gas (GHG) emissions in countries

\begin{tabular}{|l|c|c|c|}
\hline \multicolumn{1}{|c|}{ Emissions } & Estonia & Latvia & Lithuania \\
\hline Energy & 89 & 72 & 58 \\
$\quad$ (fuel combustion and emissions from fuels in & & & \\
$\quad$ all sectors, including transport) & 10 & 27.5 & 18.2 \\
Fuel combustion in transport & 5.7 & 17.7 & 17.9 \\
Agriculture & 2.7 & 2.5 & 16.6 \\
Industrial processes & 2.5 & 7 & 6.8 \\
Waste & & \\
\hline
\end{tabular}

Table 1c. $\mathrm{CO}_{2}$ emissions registered in European Union Emission Trading System (EU ETS)

\begin{tabular}{|c|c|c|c|c|c|}
\hline \multicolumn{6}{|c|}{ Big $\mathrm{CO}_{2}$ sources $(>100$ thousand tonnes) registered in EU ETS } \\
\hline & $\begin{array}{l}\text { Million } \\
\text { tonnes }\end{array}$ & $\begin{array}{l}\text { Number } \\
\text { of sources }\end{array}$ & $\begin{array}{l}\text { Share in ETS } \\
\text { emissions, \% }\end{array}$ & $\begin{array}{l}\text { Million } \\
\text { tonnes }\end{array}$ & $\begin{array}{l}\text { Share in ETS } \\
\text { emissions, \% }\end{array}$ \\
\hline Year & \multicolumn{3}{|c|}{2005} & \multicolumn{2}{|c|}{2007} \\
\hline Estonia & 11.5 & 9 & 91.3 & 14.5 & 94.6 \\
\hline Latvia & 1.9 & 6 & 63.8 & 1.9 & 65.7 \\
\hline Lithuania & 5.6 & 9 & 84.8 & 4.8 & 80.0 \\
\hline \multicolumn{6}{|c|}{ All registered in EU ETS industrial sources } \\
\hline & $\begin{array}{c}\mathrm{CO}_{2} \\
\text { emissions, } \\
\text { million } \\
\text { tonnes }\end{array}$ & $\begin{array}{l}\text { Number } \\
\text { of sources } \\
\text { of verified } \\
\text { emissions }\end{array}$ & $\begin{array}{c}\text { EU ETS share } \\
\text { in total GHG } \\
\text { emissions }\end{array}$ & $\begin{array}{c}\mathrm{CO}_{2} \\
\text { emissions, } \\
\text { million } \\
\text { tonnes }\end{array}$ & $\begin{array}{l}\text { Number of } \\
\text { sources of } \\
\text { verified } \\
\text { emissions }\end{array}$ \\
\hline Year & \multicolumn{3}{|c|}{2005} & \multicolumn{2}{|c|}{2007} \\
\hline Estonia & 12.6 & 41 & 59.3 & 15.3 & 47 \\
\hline Latvia & 2.98 & 89 & 26.7 & 2.89 & 89 \\
\hline Lithuania & 6.6 & 89 & 32.5 & 6 & 93 \\
\hline
\end{tabular}




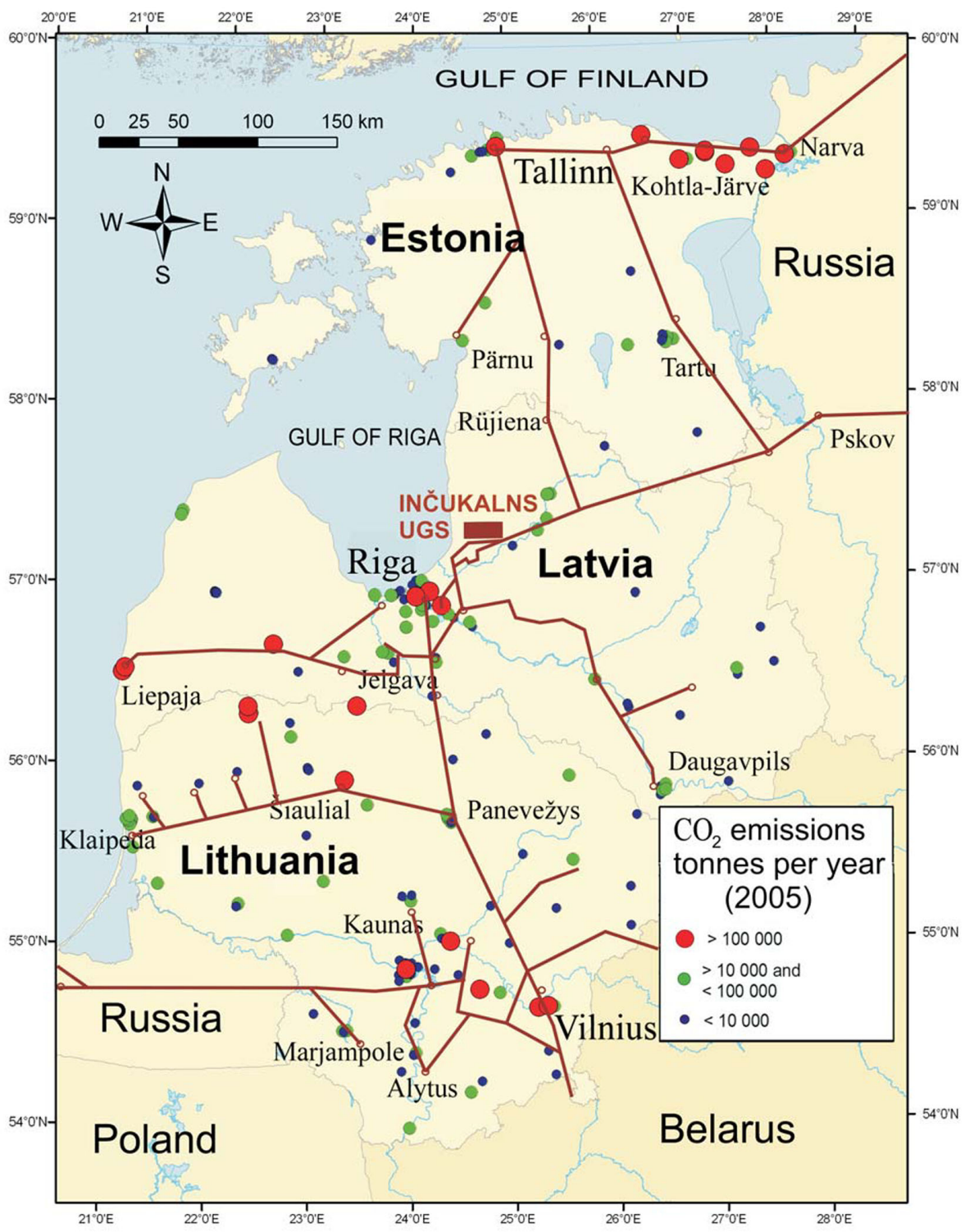

Fig. 1. Total industrial $\mathrm{CO}_{2}$ emissions (produced in 2005) in Estonia, Latvia and Lithuania registered by European Union Emissions Trading scheme are shown by circles. The biggest circles show $\mathrm{CO}_{2}$ emissions $>100,000$ tonnes per year, the middle circles show emissions from 10,000 to 100,000 tonnes per year, little circles show sources $<10,000$ tonnes per year. Solid lines show natural gas pipeline network connecting Baltic States with Russia. Little open circles show pipelines terminals. Filled rectangle shows Inĉukalns underground gas storage (UGS). 
The high GHG emission rate in Estonia results basically from the application of oil shale for power production. Main $\mathrm{CO}_{2}$ sources are located in northeast of the country, close to the oil-shale deposits. The largest $\mathrm{CO}_{2}$ sources in the Baltic countries are Estonian and Baltic Power Plants, producing respectively $7.7 \mathrm{Mt}$ and $2.25 \mathrm{Mt}$ of $\mathrm{CO}_{2}$ in 2005 , and respectively 9.4 and $2.7 \mathrm{Mt}$ of $\mathrm{CO}_{2}$ in 2007. The Kunda Nordic cement plant produced $0.746 \mathrm{Mt}$ of $\mathrm{CO}_{2}$ in 2005 and $1.17 \mathrm{Mt}$ of $\mathrm{CO}_{2}$ in 2007 (Fig. 1) Another concentration of $\mathrm{CO}_{2}$ sources has been determined in the Tallinn region. In Latvia, the main $\mathrm{CO}_{2}$ producers are located in the western part of the country. The Liepaja metallurgical enterprise emits $0.366 \mathrm{Mt}$ of $\mathrm{CO}_{2}$. Three electric power stations in the Riga area emit respectively $0.62,0.38$ and $0.14 \mathrm{Mt}$ of $\mathrm{CO}_{2}$. There are two $\mathrm{CO}_{2}$ source clusters in Lithuania, situated in the northwest and southeast of the country. The greatest GHG producer is the Mažeikiai oil refinery, emitting $1.87 \mathrm{Mt}$ of $\mathrm{CO}_{2}$ per year. The other two largest sources are Akmene cement plant and Vilnius power station producing 0.78 and $0.70 \mathrm{Mt}$ of $\mathrm{CO}_{2}$, respectively.

\section{The geological setting and stratigraphy of the Baltic basin}

The Baltic countries are located in the eastern part of the Baltic sedimentary basin that overlies the western periphery of the East European Craton (Fig. 2). Baltic basin contains the Upper Vendian at the base and all of the Phanerozoic systems as a result of protracted subsidence history. The basin is only weakly tectonized; the sedimentary layers are generally inclined to the southwest. The thickness of the sediments is less than $100 \mathrm{~m}$ in Northern Estonia, increasing to $1900 \mathrm{~m}$ in Southwestern Latvia and $2300 \mathrm{~m}$ in West Lithuania [19].

The oldest sediments are represented by up to $200 \mathrm{~m}$ thick Ediacaran (Vendian) siliciclastics aquifer and up to $120 \mathrm{~m}$ thick lowermost Cambrian Blue Clays that are distributed in the eastern half of the Baltic countries. The rest of Cambrian succession is composed of triple alternation of quartz sandstones, siltstones, and shales, occurring in different proportions across the basin. The thickness of the Cambrian aquifer is up to $170 \mathrm{~m}$ in West Lithuania. The Cambrian is overlain by a $40-250 \mathrm{~m}$ thick Ordovician shalycarbonaceous aquitard, except East Lithuania and Estonia dominated by limestones and dolostones. This shaly-carbonaceous succession grades upwards into up to $800 \mathrm{~m}$ thick package of shales of Silurian age, while carbonates predominate in the shallow periphery of the basin. Together with the Ordovician it composes the major basin-scale aquitard. Devonian sediments cover the whole territory of Latvia, Southern and Eastern Estonia, and most of Lithuania (Figs. 2, 4). The composition of Devonian sediments is variable in the section, the marly/carbonaceous packages alternating with sandy packages. Maximum thickness of $1100 \mathrm{~m}$ has been reported from West Lithuania. Some major aquifers are defined in the succession, i.e. Lowerlower Middle Devonian, Middle-lower Upper Devonian, and some smaller 


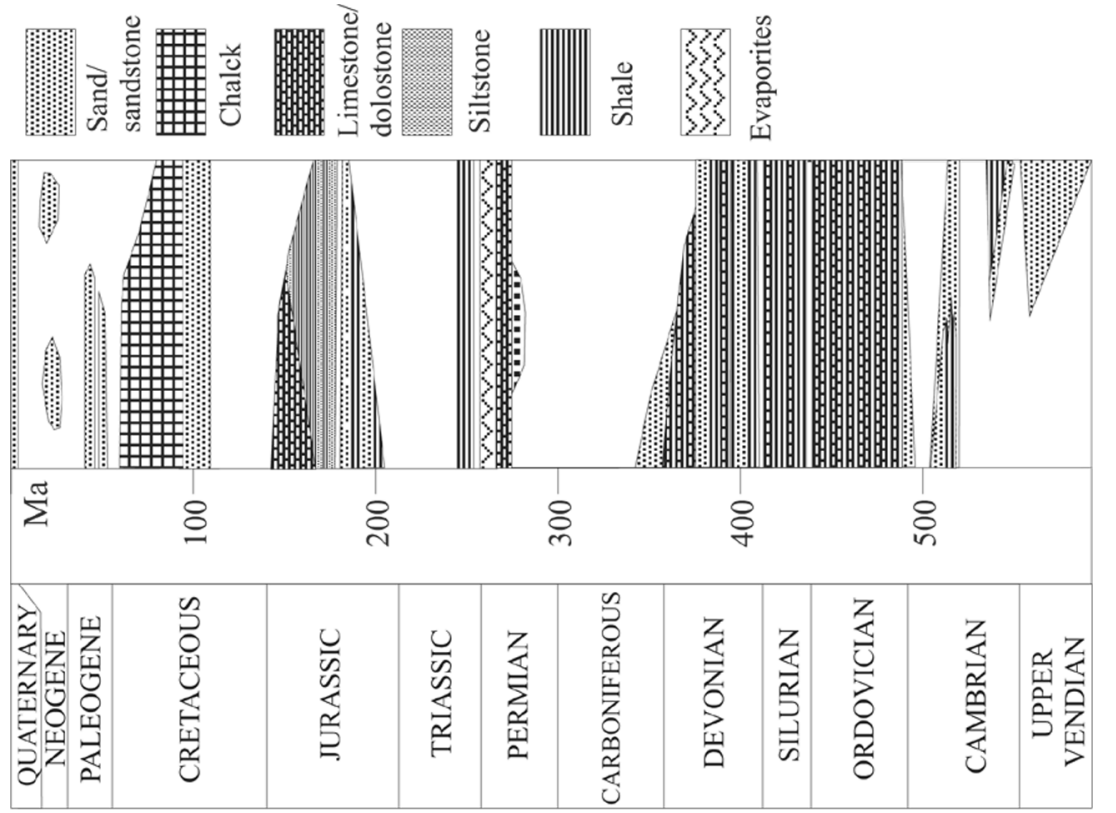

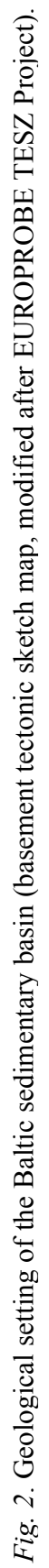

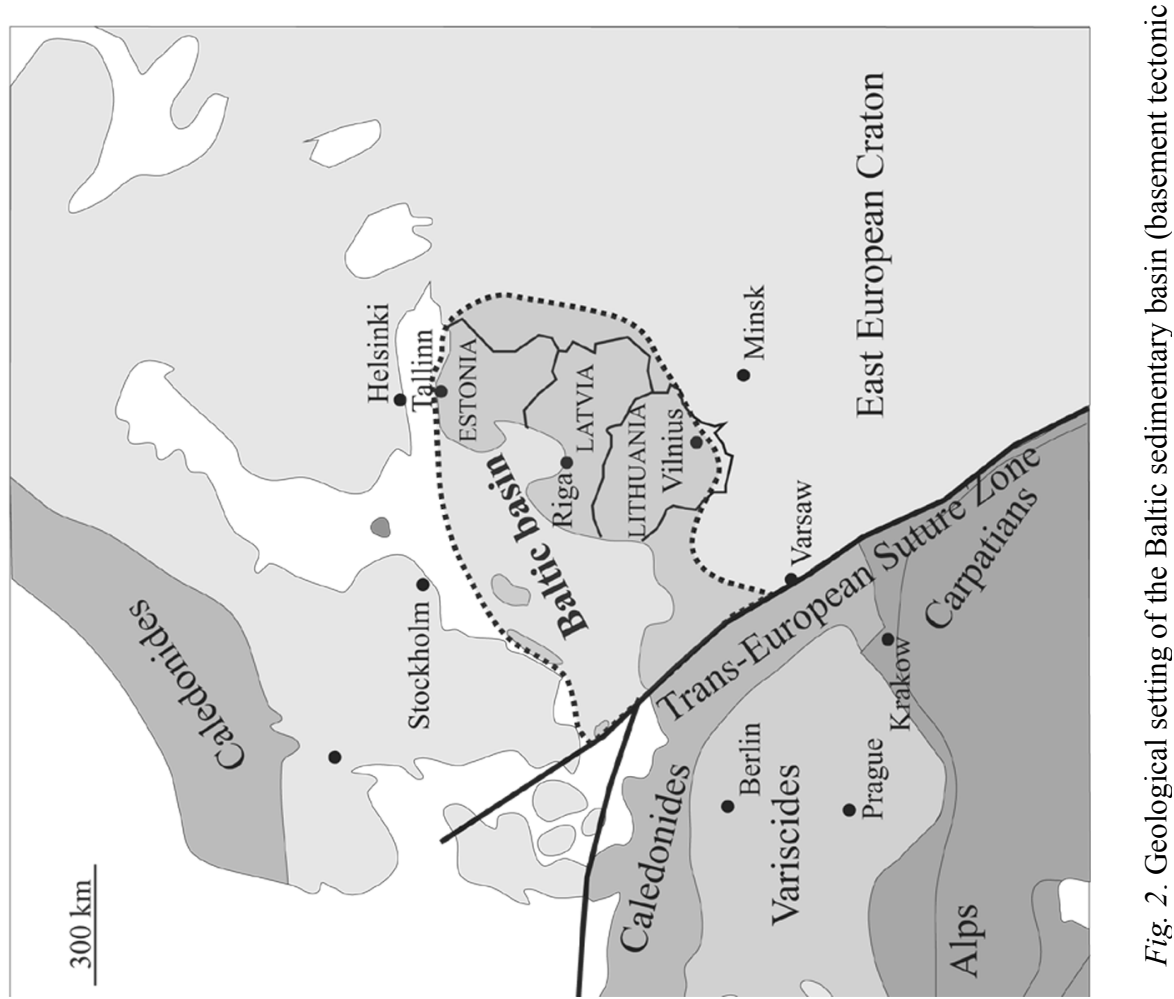


aquifers, such as Stipinai, Žagare, etc. They are distributed in most of Lithuanian and Latvian territories.

The Cambrian-lowermost Devonian succession is referred to as the Caledonian structural complex, whereas the overlying Devonian-lowermost Carboniferous succession is attributed to the less deformed Variscan structural complex. The end of the Caledonian tectonic stage was marked by the extensive faulting of the basin (Fig. 3).

The Permian, Mesozoic, and Cenozoic sediments are attributed to the Alpine structural complex. Their thickness and depths increase to southwest, reaching $600 \mathrm{~m}$ in Southwest Lithuania. Those sediments are absent in Estonia and most of Latvia, while covering the southwestern part of Lithuania. Upper Permian deposits consist of a $100 \mathrm{~m}$ thick sequence of carbonates and evaporates. The Naujoji Akmenè formation comprises an important aquifer for

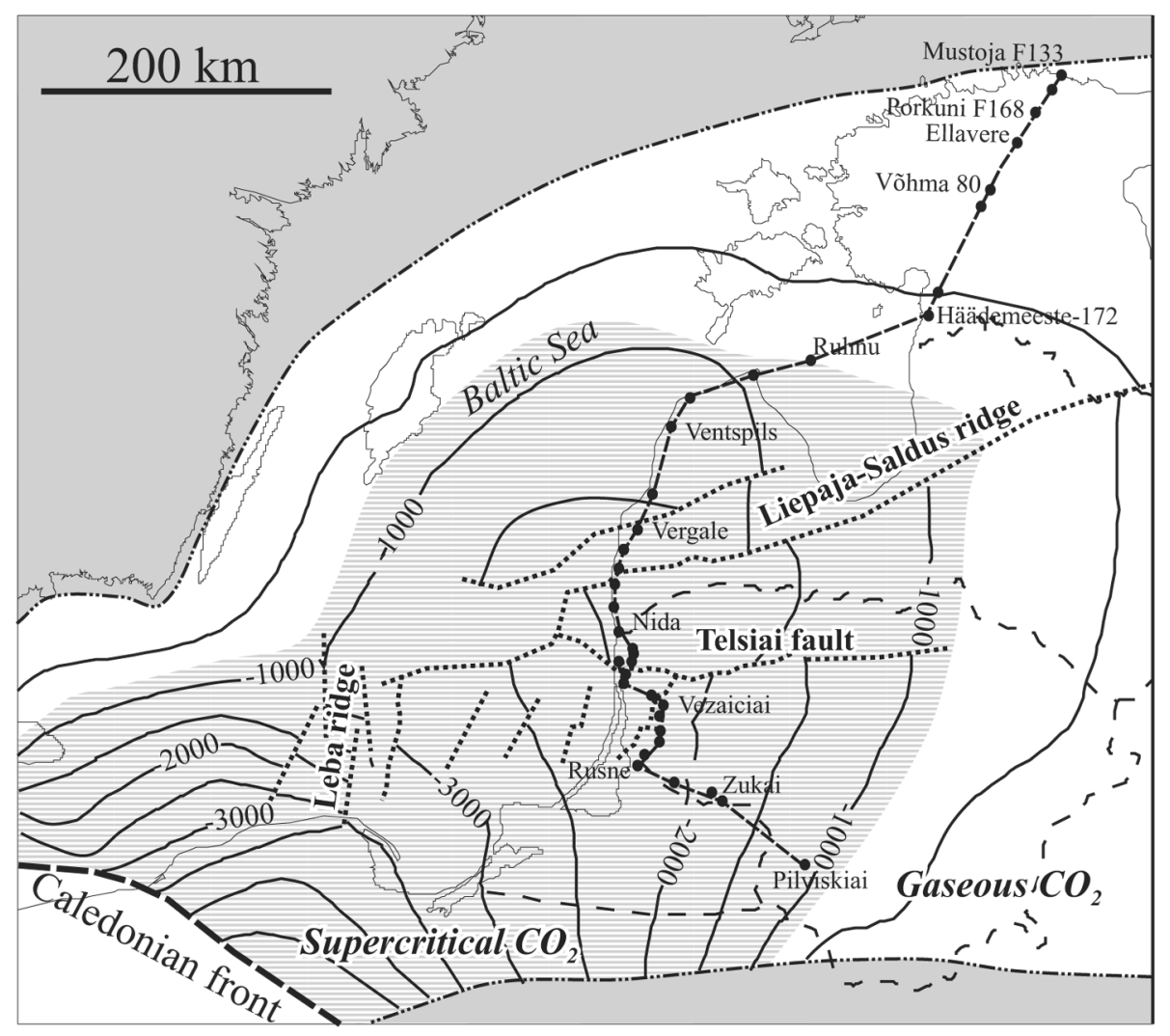

Fig. 3. Depths of top of Cambrian aquifer. The contour lines indicate the depth of the top of Cambrian. The hatched lines show major faults. The P-T fields of gaseous (white) and supercritical (dotted) state of $\mathrm{CO}_{2}$ are indicated. The line of the geological cross-section shown in Fig. 4 is indicated. 


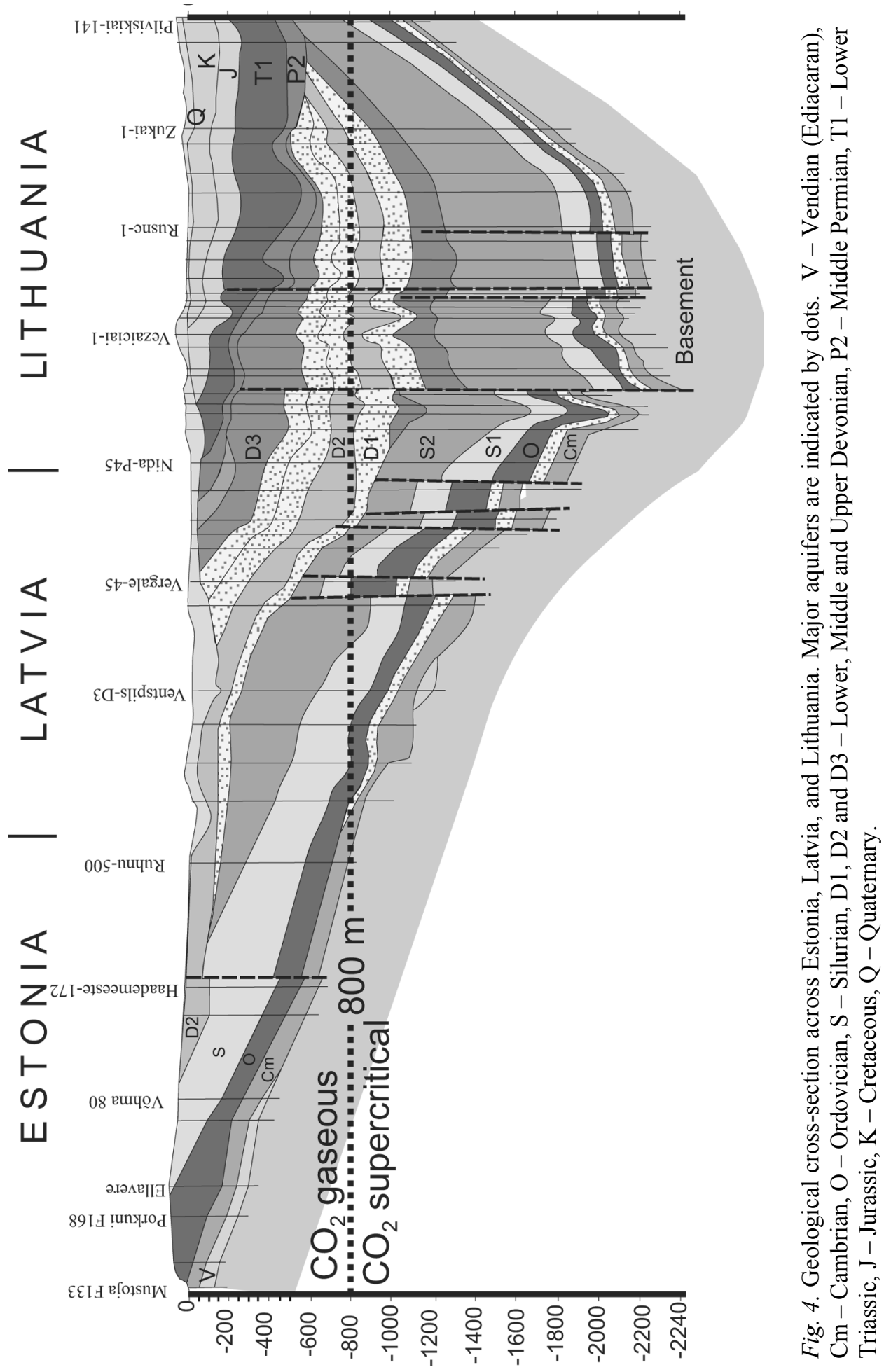


the water supply of north Lithuania. The Permian is overlain by up to $250 \mathrm{~m}$ thick Lower Triassic red-bed mudstones representing the regional-scale aquitard. The shales grade into up to $120 \mathrm{~m}$ thick Jurassic sandstones, clays, and limestones. The Cretaceous is composed of glauconite sand in the lower part and chalk and chalky marl in the upper part of the section of $140 \mathrm{~m}$ thick. In some areas of Lithuania it is used for the water supply. Cenozoic terrigenous aquifer reaching $80 \mathrm{~m}$ in thickness is known only in the southwestern part of Lithuania. The sedimentary cover is topped by the Quaternary glacial sediments varying in thickness from centimetres to a few hundred meters.

\section{Prospective formations for $\mathrm{CO}_{2}$ storage}

\section{Physical properties of the prospective geological formations}

The technology for geological $\mathrm{CO}_{2}$ sequestration in sedimentary basins has already been developed by the mining and petroleum industry. Still, there are several uncertainties concerning the volumes available for sequestration, safety, liability, and the cost associated with the $\mathrm{CO}_{2}$ transport and injection [6]. $\mathrm{CO}_{2}$ can be sequestered in geological media by:

- methane displacement in coal beds $[14,15]$,

- storage in salt caverns [7],

- storage in depleted hydrocarbon reservoirs [8], in particular when applying the enhanced oil recovery techniques [9],

- storage in deep saline aquifers through hydrodynamic trapping and mineral immobilization [10].

The Baltic basin contains a number of different formations. However, the prospective media should meet certain requirements, among which the most important are the large volume of the reservoir, suitable depth and temperature, and presence of a reliable seal (including structural tightness).

\section{Coal and salt}

No coal seams exist in the Baltic area, but thin lignite layers have been identified in Jurassic succession of Lithuania. Salt has accumulated in the Zechstein lagoon in the Kaliningrad district, while only one small salt pillow is found in Southwestern Lithuania. Consequently, these types of formations are not prospective in the Baltic region.

\section{Deep saline aquifers}

Deep saline aquifers are by far the most popular proposal for large-scale $\mathrm{CO}_{2}$ storage. These are water-saturated porous layers in the subsurface of sandstone or limestone, at present not used for any other purpose. The high water salinity renders these layers unsuitable for use as drinking water or for watering plants. 
Depending on the formation pressure and temperature, $\mathrm{CO}_{2}$ can be stored either as compressed gas or in a supercritical state $\left(P>73.8\right.$ bars, $\left.T>31^{\circ} \mathrm{C}\right)$. Carbon dioxide, injected in a supercritical state, has a much lower density and viscosity than the liquid brine it displaces. In situ, the supercritical $\mathrm{CO}_{2}$ partitions between an immiscible gas-like phase and dissolution in the aqueous phase, according to an extended version of Henry's Law, yielding a multi-phase, multi-component system. At depths greater than $800 \mathrm{~m}$ the carbon dioxide will be in a supercritical state, which enables an efficient injection method in both pipeline engineering and in filling deep pore space. It is important to realize that in the deep subsurface there is no vacant space - all pores within sandstones and limestones are filled with fluid (usually pore water). Therefore, the thermobaric conditions $P=73.8$ bars, $T=31{ }^{\circ} \mathrm{C}$ are considered the lower limit for the geological storage of $\mathrm{CO}_{2}$.

$\mathrm{CO}_{2}$ can be stored in the hydrodynamic traps (structural, stratigraphic). Some of the injected $\mathrm{CO}_{2}$ will dissolve in water or will be trapped by matrix particles. The capability of an aquifer to transmit and store $\mathrm{CO}_{2}$ is controlled by the depositional environment, structure, stratigraphy and pressure/temperature conditions. Critical factors are:

1) the regional water flow system,

2) the thickness, lateral extent and continuity of the aquifer,

3 ) the tightness of the seal above the aquifer, including the faults,

4) the capability of overburden layers above the reservoir seal to delay or diffuse leakage.

\section{Depleted oil reservoirs and enhanced oil recovery}

Depleted oil reservoirs are attractive as $\mathrm{CO}_{2}$ storage locations because they are known to have trapped and stored hydrocarbon fluids for many millions of years. The key advantage of depleted oil fields is that site-specific data for evaluating reservoirs and capability of top seals were already collected during petroleum exploration and production. $\mathrm{CO}_{2}$ has been used for enhanced oil recovery (EOR) purposes since the $1950 \mathrm{~s}$. Use of $\mathrm{CO}_{2}$ in EOR operations actually represents a form of both utilization and sequestration.

The Baltic basin contains a number of oil fields related to Cambrian siliciclastic and Ordovician and Silurian carbonaceous reservoirs. Therefore the storage of $\mathrm{CO}_{2}$ in the depleted oil fields and the EOR option are considered the potential technology in the Baltic area.

\section{Prospective aquifers in the Baltic region}

A number of aquifers have been identified in the Baltic sedimentary basin. Deep saline aquifers, not suitable for the drinking water supply, are considered prospective ones for $\mathrm{CO}_{2}$ storage.

Only two large aquifers of the Baltic States meet requirements listed above, i.e. the Lower-Middle Devonian (Pärnu-Kemeri formations) and Middle Cambrian aquifers buried to depths exceeding $800 \mathrm{~m}$ in the central and western parts of the Baltic basin (Fig. 3). 
The Cambrian reservoir is distributed in all Baltic countries. Its depth varies from outcrops in Estonia to more than $2 \mathrm{~km}$ in West Lithuania (Fig. 3). The depth of the reservoir exceeds $800 \mathrm{~m}$ in West Latvia, West Lithuania, North Poland, and in the Baltic offshore, while Estonia is beyond the limit of the supercritical state of $\mathrm{CO}_{2}$. The reservoir is composed of quartz sandstones with subordinate siltstones and shales. The thickness of the aquifer is in the range of 20-70 $\mathrm{m}$ [19]. Due to considerable variations in depth and temperature, the porosity of sandstones changes drastically across the basin, from $20-30 \%$ in the northern and eastern shallow part of the basin to less than $5 \%$ in the central and western parts of the basin [24]. The Middle Cambrian aquifer is sealed by a thick $(500-900 \mathrm{~m})$ shaly package of Ordovician-Silurian age representing a reliable seal rock.

The Pärnu-Kemeri aquifer is distributed in the central part of the basin (Fig. 5). Its depth exceeds $800 \mathrm{~m}$ only in West Lithuania and the southeastern part of the Baltic offshore where it reaches $1100 \mathrm{~m}$. The aquifer is composed of arkosic sandstones containing siltstone and shaly layers. The net-to-gross ratio is of order of $0.7-0.8$ [25]. Average porosity of sandstones is $26 \%$; permeability is in the range of $0.5-2 \mathrm{D}$. Total thickness of the aquifer varies from 100 to $160 \mathrm{~m}$ in West Lithuania. The aquifer is covered by $80-120 \mathrm{~m}$ thick marlstones attributed to the Narva Formation constituting a basin-scale aquitard.

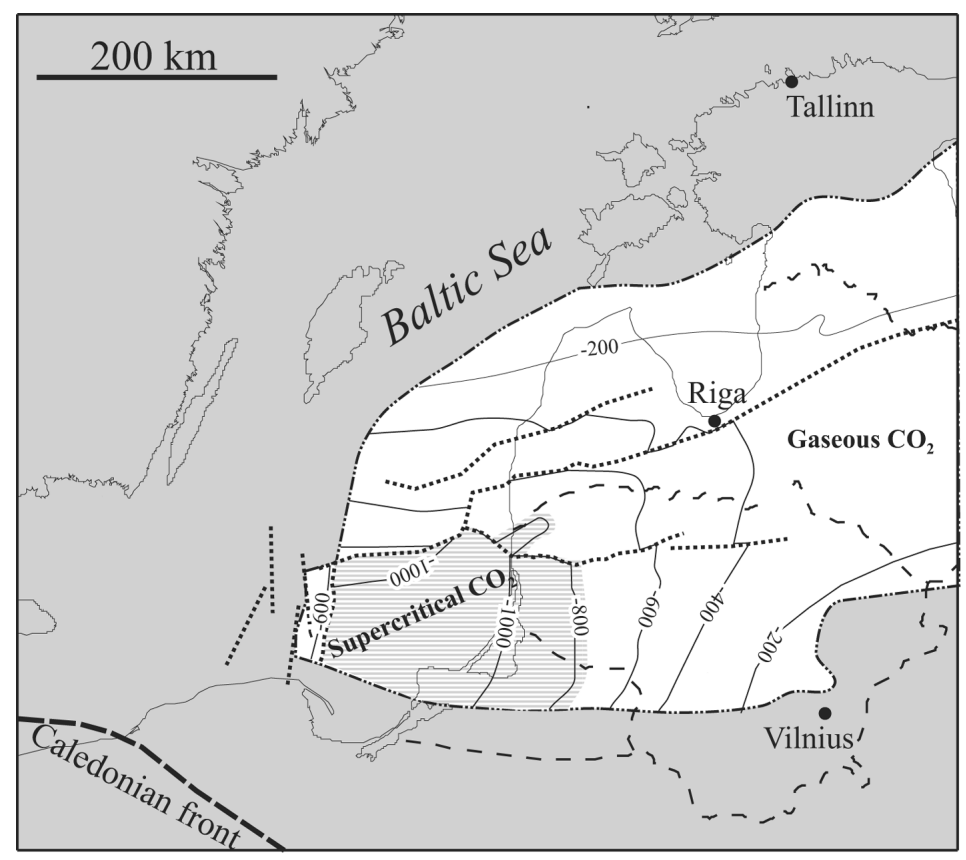

Fig. 5. Depths of top of Pärnu-Kemeri aquifer. The contour lines indicate the depth of the top of Devonian. The hatched lines show major faults. The P-T fields of gaseous (white) and supercritical (dotted) state of $\mathrm{CO}_{2}$ are indicated. 
Upon injection into saline aquifers, carbon dioxide may be stored by (1) hydrodynamic (structural) trapping, (2) solubility trapping (carbon dioxide dissolved in aquifer water), (3) residual trapping, and (4) mineral trapping. Solubility and mineral trapping are the most important long-term solutions to carbon dioxide sequestration in geological media. However, these processes involve larger proportion of injected $\mathrm{CO}_{2}$ only 100 years after the injection, whereas hydrodynamic trapping becomes effective immediately and can be compared to existing natural analogues.

\section{Structural trapping}

Structuring of the Cambrian reservoir varies across the basin. The most intense faulting and formation of associated local uplifts (potential traps) took place in Central Latvia (e.g. Liepaja-Saldus ridge) [28] (Fig. 3). A dense network of faults has been identified in West Lithuania and Estonia, but these faults are of much lower order, and the related uplifts are much smaller in size.

Fifteen major structures, with estimated storage capacity exceeding $10 \mathrm{Mt}$ $\mathrm{CO}_{2}$, have been identified in West Latvia (Fig. 6). One of these structures has been used for underground gas storage for several decades, which proves the tightness of the structural traps in Latvia (Inčukalns UGS).

The storage capacity of a structural trap is estimated:

$$
M_{\mathrm{CO} 2}=A \times h \times \varphi \times \rho_{\mathrm{CO} 2 \mathrm{r}} \times S,
$$

where $M_{\mathrm{CO} 2}$ is the storage capacity $(\mathrm{kg}), A$ is the area of a closure $\left(\mathrm{m}^{2}\right), h$ is the net thickness of reservoir sandstones (m) (typically 20-40 m in Latvia and Lithuania), $\varphi$ is the porosity (typically ranges from $0.25-0.20$ in Central Latvia and Central Lithuania to 0.06 in West Lithuania), $\rho_{\mathrm{CO} 2 \mathrm{r}}$ is the in situ

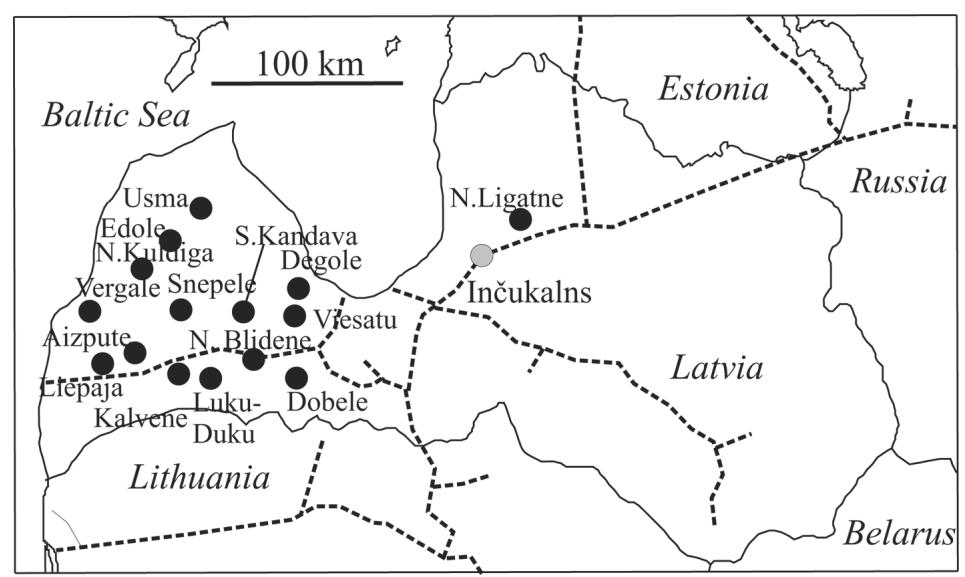

Fig. 6. Major Cambrian aquifer structures $\left(\mathrm{CO}_{2}\right.$ storage potential exceeding $\left.10 \mathrm{Mt}\right)$ of Latvia (black circles) and Inčukalns underground gas storage (grey circle). Hatched line shows gas pipelines. 
$\mathrm{CO}_{2}$ density at reservoir conditions (ranges from $600 \mathrm{~kg} / \mathrm{m}^{3}$ in West Lithuania to $750 \mathrm{~kg} / \mathrm{m}^{3}$ in Central Lithuania and Central Latvia), $S$ is the sweeping efficiency, often also referred to as the storage efficiency (assumed 0.35 for both reservoirs).

The total capacity of large structures of Latvia is estimated to the more than $300 \mathrm{Mt}$ of $\mathrm{CO}_{2}$, with the potential of the greatest uplifts reaching 40$80 \mathrm{Mt}$ of $\mathrm{CO}_{2}$. The major $\mathrm{CO}_{2}$ emitting sources are located close to major uplifts. Furthermore, the $\mathrm{CO}_{2}$ sources and potential traps are located close to the existing gas supply pipelines, which potentially reduces the cost of $\mathrm{CO}_{2}$ transportation.

The capacities of more than 100 Cambrian local uplifts identified in Lithuania were evaluated recently [25]. The two largest Vaskai and Syderiai aquifer structures can store only 3.5 and $5.4 \mathrm{Mt}$ of $\mathrm{CO}_{2}$, respectively. The rest of the structures are of much lesser volume. Therefore, the hydrodynamic trapping in Cambrian aquifer structures has no prospects in Lithuania.

No structural traps have been identified in the Pärnu-Kemeri aquifer, neither in Lithuania nor in Latvia due to low-intensity tectonic deformation of the Variscan structural complex $[25,28,30]$.

\section{Solubility trapping}

The solubility trapping is not restricted to particular structures. The solubility of $\mathrm{CO}_{2}$ ranges from $2 \%$ to $6 \%$, depending on the brine salinity, temperature, and pressure $[12,31,32]$. However, the large volume of a regional-scale aquifer provides an attractive alternative for $\mathrm{CO}_{2}$ disposal. The solution time is of order of $10^{2}-10^{3}$ years, which is considerably longer than the hydrodynamic trapping process $[33,34]$. Before dissolving, the $\mathrm{CO}_{2}$ phase migrates towards the basin margins, which may cause the risk of gas escape either through the faults or shallow margins of the basin. Therefore, the safe distance of gas migration should be evaluated before selecting prospective sites for $\mathrm{CO}_{2}$ injection.

The solubility trapping potential has been calculated using the approach presented in [12]. It accounts for the brine salinity, temperature, pressure and reservoir properties that vary considerably across the Baltic basin. The solubility of $\mathrm{CO}_{2}$ in Cambrian formation water varies from $25-30 \mathrm{~kg} / \mathrm{m}^{3}$ in West Lithuania to $40-50 \mathrm{~kg} / \mathrm{m}^{3}$ in East Lithuania and Latvia (Table 2). The $\mathrm{CO}_{2}$ storage potential changes westwards from $0.4 \mathrm{Mt} / \mathrm{km}^{2}$ to $0.05 \mathrm{Mt} / \mathrm{km}^{2}$. The calculated total solubility trapping capacity is as high as $11 \mathrm{Gt}$ of $\mathrm{CO}_{2}$ within the area of the supercritical state of the carbon dioxide.

The Pärnu-Kemeri aquifer is characterised by better reservoir properties, but has a smaller area of extent than the Middle Cambrian reservoir. $\mathrm{CO}_{2}$ solubility ranges from $36 \mathrm{~kg} / \mathrm{m}^{3}$ in the deep part of the basin to $60 \mathrm{~kg} / \mathrm{m}^{3}$ in the shallow periphery of the basin. In West Lithuania the storage capacity of the reservoir is about one Mt of $\mathrm{CO}_{2}$ in one $\mathrm{km}^{2}$ area. The total onshore potential of this formation is estimated as high as one $\mathrm{Gt}$ of $\mathrm{CO}_{2}$. 
Table 2. Solubility trapping in Cambrian reservoir in West, Central, and East Lithuania

\begin{tabular}{|l|c|c|c|}
\hline \multicolumn{1}{|c|}{ Parameters } & West Lithuania & Central Lithuania & East Lithuania \\
\hline Aquifer temperature, ${ }^{\circ} \mathrm{C}$ & 75 & 55 & 40 \\
Aquifer Pressure, $\mathrm{MPa}$ & 20 & 15 & 10 \\
Salinity, g/l & 160 & 110 & 90 \\
$\mathrm{CO}_{2}$ solubility, $\mathrm{kg} / \mathrm{m}^{3}$ & 28.1 & 35.6 & 40.9 \\
Effective thickness, $\mathrm{m}$ & 20 & 35 & 40 \\
Porosity, \% & 10 & 20 & 25 \\
Solubility storage in 1 km & 0.056 & 0.249 & 0.409 \\
area, Mt of $\mathrm{CO}_{2}$ & & & \\
\hline
\end{tabular}

Furthermore, the mineral trapping that involves a series of interactions between the formation mineralogy and $\mathrm{CO}_{2}$-enriched aquifer waters, can convert $\mathrm{CO}_{2}$ to carbonate, an immobile and harmless mineral that will be stored for millions to hundreds of millions of years [13,35]. Reactions with $\mathrm{Ca} / \mathrm{Mg} / \mathrm{Fe}$-bearing silicate minerals are the most promising for carbon sequestration because these silicates neutralize the added acidic $\mathrm{CO}_{2}$ and provide alkali metals that trap $\mathrm{CO}_{2}$ through the precipitation of carbonate [14]. These reactions can be summarized as follows [36]:

$$
\begin{aligned}
& \mathrm{Ca} / \mathrm{Mg} / \mathrm{Fe} \text { feldspar }+ \text { clays }+\mathrm{CO}_{2}+\mathrm{H}_{2} \mathrm{O} \\
& \quad=\text { kaolinite }+\mathrm{Ca} / \mathrm{Mg} / \mathrm{Fe} \text { carbonate }+ \text { quartz }
\end{aligned}
$$

The Middle Cambrian reservoir comprises quartz sandstones that are practically not reactive to carbon dioxide. The Pärnu-Kemeri sandstones contain clay admixture (up to $10 \%$ ) and feldspar grains (up to $15 \%$ ). Therefore they have a potential for permanent immobilisation of carbon dioxide in mineral form. Assuming the rock capacity of $10 \mathrm{~kg} / \mathrm{m}^{3}$ [12], the sequestration potential can be evaluated to reach $5.6 \mathrm{Gt}$ of $\mathrm{CO}_{2}$ (onshore).

The technology of $\mathrm{CO}_{2}$ mineral trapping with waste oil shale ash is under development in Estonia. Investigations of Tallinn University of Technology performed within the framework of Nordic-Baltic project $\mathrm{NoCO}_{2}$ and supported by SC Eesti Energia and Ministry of Environment of Estonia show that the amount of $\mathrm{CO}_{2}$ which is possible to bind with oil shale ash will cover about $10-12 \%$ of the large industrial $\mathrm{CO}_{2}$ emissions in Estonia (37-41).

\section{Depleted oil fields}

A number of oil fields have been discovered in the Baltic basin, mainly in the Middle Cambrian reservoir [42,43]. Oil fields are exploited in West Lithuania, Kaliningrad District and offshore Poland. In Lithuania, oil fields are confined to two major tectonic zones, i.e. the Telšiai fault zone and the Gargždai fault zone. Some oil shows (and a small Kuldiga oil field) were discovered in Cambrian and Ordovician reservoirs in Latvia [43]. The Silurian reefs contain small oil fields in Central Lithuania, which are not exploited. 
The Cambrian oil-bearing structures are commonly as large as $3 \times 5 \mathrm{~km}^{2} \times 20-40 \mathrm{~m}$. In Lithuania, ten oil fields are presently exploited. The size of oil fields ranges from 16,000 tonnes to $1,400,000$ tonnes of the recoverable oil. The storage potential of the largest oil fields in West Lithuania reaches two $\mathrm{Mt}$ of $\mathrm{CO}_{2}$. The total potential in Lithuania is estimated at $7.6 \mathrm{Mt}$ of $\mathrm{CO}_{2}$, which is just a little more than the annual stationary $\mathrm{CO}_{2}$ emissions of the country.

Another option is the utilisation of carbon dioxide for oil recovery [5]. Most of the oil fields have reached the tail phase, and EOR can prolong the lifetime of those oil fields. The oil is light and exceeds $35 \mathrm{API}^{\circ}$ [44] meaning that $\mathrm{CO}_{2}$ could be injected in miscible conditions - a favourable factor for $\mathrm{CO}_{2}$ sequestration. The estimated total EOR net volume of $\mathrm{CO}_{2}$ is $5.6 \mathrm{Mt}$.

\section{Conclusions}

$\mathrm{CO}_{2}$ sources are distributed unevenly in the Baltic countries and the types of $\mathrm{CO}_{2}$ sources vary considerably. Major emissions are concentrated in the coastal area of the Gulf of Finland in Estonia. Due to the utilisation of oil shale for energy production, $\mathrm{CO}_{2}$ emissions produced by two largest Estonian power plants exceed the $\mathrm{CO}_{2}$ produced by all of the Lithuanian $(6.6 \mathrm{Mt})$ and Latvian $(2.98 \mathrm{Mt})$ stationary sources. During $2007, \mathrm{CO}_{2}$ emissions from Estonian industrial sources increased for about $18 \%$ owing to increased energy production of these two largest in the region power plants. Baltic countries are situated within the Baltic sedimentary basin that contains a number of regional-scale aquifers. However, only two of these, the Lower-Middle Devonian and Middle Cambrian reservoirs, meet the basic requirements for $\mathrm{CO}_{2}$ storage. The Cambrian prospective area encompasses West Lithuania and West Latvia and most of the Baltic Sea territory, while the aquifers in Estonia are too shallow, they have no reliable seals and they all could be used for drinking water supply. The transportation of carbon dioxide from Northern Estonian sources to Latvian structures could be an alternative option (250-400 $\mathrm{km}$ distance to the potential sites in Latvia).

All major $\mathrm{CO}_{2}$ sources of Latvia are located within the prospective Cambrian area. The most prospective storage of $\mathrm{CO}_{2}$ is related to 15 large uplifts the total capacity of which exceeds $300 \mathrm{Mt}$ that amounts more than 150 years of country's $\mathrm{CO}_{2}$ stationary emissions. Furthermore, the structures are rather close to existing pipelines.

Only the north-western cluster of $\mathrm{CO}_{2}$ sources is located within the prospective area of the Cambrian reservoir and only one source is within the Devonian prospective area in Lithuania. The structural trapping is not an option for Lithuania, as the uplifts are too small. Alternatively, the solubility trapping could be considered as having a high potential. Together with the mineral trapping it should cover industry needs for hundreds of years. However, these technologies are still immature. Basic problems are the poor 
knowledge on the migration velocity of the $\mathrm{CO}_{2}$ plume and solubility rate that are important parameters for the safety assessment. Also, several problems still have to be solved to activate this potential, such as dissolution enhancement, monitoring, etc.

The Inčukalns underground gas storage operating in Latvia, which is used for the supply of natural gas to Latvia, Estonia and Lithuania, is an example of collaboration in the region [45]. The existing infrastructure of pipelines, already connecting the large Baltic $\mathrm{CO}_{2}$ sources with Latvian prospective structures, provides a possibility of reducing the price of the $\mathrm{CO}_{2}$ pipelines and some prospect for geological storage of the substantial Baltic industrial $\mathrm{CO}_{2}$ emissions in the most favourable geological conditions available in Latvia.

\section{Acknowledgements}

This research was funded by EU GEOCAPACITY project FP6-518318 and CO2NET EAST project FP6-038946 and by the governmental target funding project No SF0320080s07 from Estonian Ministry of Education and Research and was partially supported by Science and Study Foundation of Lithuania (contract number 2 T-37/05). The paper was greatly improved by comments by Prof. Bruno Saftic and Prof. Väino Puura.

\section{REFERENCES}

1. Metz, B., Davidson, O., Coninck, H., Manuela,L., Meyer, L. (eds). Carbon Dioxide Capture and Storage. - IPCC Special Report, 2006.

2. White, C. M., Strazisar, B. R., Granite, E. J., Hoffman, J. S., Pennline, H.W. Separation and capture of $\mathrm{CO}_{2}$ from large stationary sources and sequestration in geological formations - coalbeds and deep saline aquifers // J. Air Waste Manage. Assoc. 2003. Vol. 53, No. 6. P. 645-715.

3. Mackenzie, F. T., Lerman, A. Carbon in the Geobiosphere - Earth's Outer Shell. - Springer, 2006.

4. Lokhorst, A., Wildenborg, $T$. Introduction on $\mathrm{CO}_{2}$ geological storage. Classification of storage options // Oil and Gas Science and Technology, Rev. IFP. 2005. Vol. 60, No. 3. P. 513-515.

5. Crawford, H. R., Neill, G. H., Bucy, B. J., Crawford, P. B. Carbon dioxide: A multipurpose additive for effective well stimulation // J. Pet. Technol. 1963. No. 237. P. 52-64.

6. Herzog, H. J., Drake, E. M., Adams, E. E. $\mathrm{CO}_{2}$ Capture, Reuse, and Storage Technologies for Mitigating Global Climate Change. - Final Report, DOE No. DE-AF22-96PC01257, 1997.

7. Bradley, R. A., Watts, E. C., Williams, E. R.. Limiting Net Greenhouse Gas Emissions in the U.S. - Report to the US Congress, 1991.Vol. 1, US DOE. 
8. Winter, E. M., Bergman, P. D. Availability of depleted oil and gas reservoirs for disposal of carbon dioxide in the United States// Energy Convers. Manage. 1993. Vol. 34, No. 9-11. P. 1177-1187.

9. Blunt, M., Fayers, F. J., Orr, F. M. Carbon dioxide in enhanced oil recovery // Energy Convers. Manage. 1993. Vol. 34, No. 9-11. P. 1197-1204.

10. Bachu, S., Gunter, W.D., Perkins, E. H. Aquifer disposal of $\mathrm{CO}_{2}$ : Hydrodynamic and mineral trapping // Energy Convers. Manage. 1994. Vol. 35, No. 4. P. 269-279.

11. Law, D. H.-S., Bachu, S. Hydrogeological and numerical analysis of $\mathrm{CO}_{2}$ disposal in deep aquifers in the Alberta sedimentary basin // Energy Convers. Manage, 1996. Vol. 37, No. 6-8. P. 1167-1174.

12. Bachu, S., Adams, J. J. Sequestration of $\mathrm{CO}_{2}$ in geological media in response to climate change: capacity of deep saline aquifers to sequester $\mathrm{CO}_{2}$ in solution // Energy Convers. Manage. 2003. Vol. 44, No. 20. P. 3151-3175.

13. Bruant, R. G., Guswa, A. J., Celia, M. A., Peters, C. A. Safe storage of $\mathrm{CO}_{2}$ in deep saline aquifers // Environ. Sci. Technol. 2002. Vol. 36, No. 11. P. 241-245.

14. Gunter, W. D., Gentzis, T., Rottenfusser, B. A., Richardson, R. J. H. Deep coalbed methane in Alberta, Canada: A fuel resource with the potential of zero greenhouse emissions // Energy Convers. Manage. 1997. Vol. 38, Supplement 1. P. S217-S222.

15. Pashin, J. C., McIntyre, M. R. Temperature-pressure conditions in coalbed methane reservoirs of the Black Warrior basin: implications for carbon sequestration and enhanced coalbed methane recovery // Int. J. Coal Geol. 2003. Vol. 54. P. 167-183.

16. Greenhouse Gas Emissions in Estonia 1990-2005. National Inventory Report to the UNFCCC secretatriat. - Common Reporting Formats (CRF) 1990-2005. Ministry of Environment. Tallinn, 2007. (http://unfccc.int/national_reports/ annex i ghg inventories/national_inventories_submissions/items/3929.php).

17. Rimša, H., Krumholde, S., Gancone, A., Sinics, L., Cakars, I., Abolina, L. Latvia's National Inventory Report - submitted under United Nations Convention on Climate Change. - Common Reporting Formats (CRF) 1990 2005. Riga, 2007. (http://unfccc.int/ national_reports/annex_i_ghg_inventories/ national_inventories_submissions/items/3929.php).

18. National Greenhouse Gas Emission Inventory Report 2007 of the Republic of Lithuania. Reported Inventory 1990-2005. - Annual report under the UN Framework Convention on Climate Change. Vilnius, 2007.

19. Paškevičius, J. The Geology of the Baltic Republics. - Vilnius, 1997.

20. Shogenova, A., Kirsimäe, K, Bitjukova, L, Jõeleht, A, Mens, K. Physical properties and composition of cemented siliciclastic Cambrian rocks, Estonia // Nordic Petroleum Technology Series: V, Research in Petroleum Technology / I. Fabricius (ed.). Norway: Nordisk Energiforskning ÅS, 2001. Vol. 5. P. 123 149.

21. Sliaupa, S., Rasteniene, V., Lashkova, L, Shogenova, A. Factors controlling petrophysical properties of Cambrian siliciclastic deposits of Central and Western Lithuania// Nordic Petroleum Technology Series: V, Research in Petroleum Technology/I. Fabricius (ed.). Norway: Nordisk Energiforskning ÅS, 2001. Vol. 5. P. 157-180.

22. Jõeleht, A., Kirsimäe, K., Shogenova, A., Šliaupa, S., Kukkonen, I. T., Rasteniene, $V$., Zabele, A. Thermal conductivity of Cambrian siliciclastic rocks from Baltic paleobasin // Proc. Acad. Sci. Estonia. Geol. 2002. Vol. 51, No. 1. P. 5-15. 
23. Shogenova, A, Mens, K., Sliaupa, S., Rasteniene, V., Jõeleht, A., Kirsimäe, K., Zabele, A., Freimanis, A. Factors influenced porosity of the siliciclastic rocks in the Baltic Cambrian basin // Extended Abstracts. Vol. 2. 64th EAGE Conference and Technical Exhibition, Florence 26-30 May 2002. - The Netherlands: European Association of Geoscientists \& Engineers, 2002. P. 218. P. 1-5.

24. Šliaupa, S., Hoth, P., Shogenova, A., Huenges, E., Rasteniene, V., Freimanis, A., Bityukova, L., Joeleht, A., Kirsimäe, K., Laskova, L., Zabele, A. Characterization of Cambrian reservoir rocks and their fluids in the Baltic States (CAMBALTICA) // Cleaner Energy Systems Through Utilization of Renewable Geothermal Energy Resources / W. Bujakowski (ed.). Krakow: Kajc, 2003. P. 61-73.

25. Šliaupa, S., Satkūnas, J., Šliaupienè, R. Prospects of $\mathrm{CO}_{2}$ geological sequestration in Lithuania // Geologija. 2005. No 51. P. 19-28 [in Lithuanian with English summary].

26. Geological Structures for the Establishment of Underground Gas Storages. Riga: Latvian Environment, Geology and Meteorology Agency, 2007.

27. Shogenova, A., Sliaupa, S., Shogenov, K., Vaher, R., Sliaupiene, R. Geological Storage of $\mathrm{CO}_{2}$ - Prospects in the Baltic States // 69th EAGE Conference \& Exhibition, Incorporating SPE EUROPEC, London. Extended Abstracts. EAGE, 2007. P. 228. P. 1-6.

28. Brangulis, A., Kanevs, S. Latvijas Tektonika. - Riga, 2002 [in Latvian].

29. Šliaupa, S., Laškovas, E., Lazauskienè, J., Laškova, L., Sidorov, V. The petroleum system of the Lithuanian offshore region// Zeitschrift für Angewandte Geology. Hannover, 2004. Sonderheft 2. P.41-59.

30. Stirpeika, A. Tectonic Evolution of the Baltic Syneclise and Local Structures in the South Baltic Region with Respect to their Petroleum Potential. - Vilnius, 1999.

31. Kaszuba, J. P, Janecky, D. R., Snow, M. G. Carbon dioxide reaction processes in a model brine aquifer at $200{ }^{\circ} \mathrm{C}$ and 200 bars: implications for geologic sequestration of carbon // Appl. Geochem. 2003. Vol. 18, No. 7. P. 1065-1080.

32. Spycher, N., Pruess, K., Ennis-King, J. $\mathrm{CO}_{2}-\mathrm{H}_{2} \mathrm{O}$ mixtures in the geological sequestration of $\mathrm{CO}_{2}$. Assessment and calculation of mutual solubilities from 12 to $100{ }^{\circ} \mathrm{C}$ and up to 600 bar // Geochim. Cosmochim. Acta. 2003. Vol. 67, No. 16. P. 3015-3031.

33. Ennis-King, J., Gibson-Poole, C. M., Lang, S. C., Paterson, L. Long-term numerical simulation of geological storage of $\mathrm{CO}_{2}$ in the Petrel Sub-basin, North West Australia// Greenhouse Gas Control Technologies. Proc. 6th Int. Conf. on Greenhouse Gas Control Technologies, 1-4 October 2002, Kyoto, Japan / J. Gale, Y. Kaya (Eds.). Elsevier Science, 2003. Addendum. P. 11-16.

34. Van der Meer, L. G. H., Hartman, J., Geel, C., Kreft, E. Re-injecting $\mathrm{CO}_{2}$ into an offshore gas reservoir at a depth of nearly 4000 metres sub sea // Proc. 7th Int. Conf. on Greenhouse Gas Control Technologies. Vol. 1. Peer-Reviewed Papers and Plenary Presentations / E. S. Rubin, D. W. Keith and C. F. Gilboy (Eds.). UK: IEA Greenhouse Gas Programme, Cheltenham, 2003.

35. Pruess, K., Garcia, J. Multiphase flow dynamics during $\mathrm{CO}_{2}$ disposal in aquifers // Environ. Geol. 2003. 42. P. 282-295.

36. Hitchon, B. (ed.). Aquifer Disposal of Carbon Dioxide: Hydrodynamics and Mineral Trapping - Proof of Concept. - Canada: Geoscience Publishing Ltd., 1996. 
37. Kuusik, R., Veskimäe, H., Kaljuvee, T., Parts, O. Carbon dioxide binding in the heterogeneous systems formed by combustion of oil shale. 1. Carbon dioxide binding at oil shale ash deposits // Oil Shale. 2001. Vol. 18, No. 2. P. 109-122.

38. Kuusik, R., Türn, L., Trikkel, A., Uibu, M. Carbon dioxide binding in the heterogeneous systems formed at combustion of oil shale. 2. Integrations of system components - thermodynamic analysis // Oil Shale. 2002. Vol. 19, No. 2. P. 143-160.

39. Kuusik, R., Veskimäe, H., Uibu, M. Carbon dioxide binding in the heterogeneous systems formed by combustion of oil shale. 3. Transformations in the system suspension of ash - flue gases // Oil Shale. 2002.Vol. 19, No. 3. P. 277-288.

40. Uibu, M., Trikkel, A., Kuusik, R. Transformations in the solid and liquid phase at aqueous carbonization of oil shale ash // WIT Transactions on Ecology and the Environment 2007: ECOSUD VI, Coimbra (Portugal) / E. Tiezzi, J. C. Marques, C. A. Brebbia, S. E. Jorgensen (eds.). WIT Press, 2007. (106). P. 473-483.

41. Uibu, M., Kuusik, R. Concept for $\mathrm{CO}_{2}$ mineralization by oil shale waste ash in Estonian power production // Proc. of IGEC III: The $3^{\text {rd }}$ Int. Green Energy Conference, Västeras, Mälardalens University, Sweden, 2007 / Yan, Jinyue (ed.) CD-ROM. P. 1075-1085.

42. Domžalski, J., Górecki, W., Mazurek, A., Myśko, A., Strzeteski, W., Szamalek, K. The prospects for petroleum exploration in the eastern sector of Southern Baltic as relevant by sea bottom geochemical survey correlated with seismic data // Prszegląd Geologiczny. 2004. Vol. 52, No. 8/2. P. 792-799.

43. Brangulis, A. P., Kanev, S. V., Margulis, L. S., Pomerantseva, R. A. Geology and hydrocarbon prospects of the Paleozoic in the Baltic region // Petroleum Geology of NW Europe. / Proc. of the 4th Conference, London, March-April, 1992 J. R. Parker (ed.). Geol. Soc., 1993.

44. Zdanavičiūtè, O., Sakalauskas, K. Petroleum Geology of Lithuania and Southeastern Baltic. - Vilnius, GGI, 2001

45. Davis, A., Jesinska, A., Kreslins, A., Zebergs, $V$., Zeltins, $N$. Increasing role of underground gas storages for reliable supply of gas to Latvia, Lithuania, Estonia, Finland and NW Russia and prospects of development of Incukalns underground gas storage. - 23rd World Gas Conference, Amsterdam, 5-9 June 2006 (CD).

Presented by A. Raukas

Received December 10, 2007 